\title{
Evaluation of Ascitic Fluid Cytology in a Tertiary Hospital in Nigeria
}

\author{
Nwafor $\mathrm{CC}^{1^{*}}$, Obioha $\mathrm{K}^{2}$ Akhiwu TO ${ }^{3}$. \\ ${ }^{\prime}$ Department of Pathology, University of Uyo \\ ${ }^{2}$ Department of Histopathology, University of Uyo Teaching \\ Hospital. \\ ${ }^{3}$ Department of Histopathology, University of Benin Teaching \\ Hospital \\ doi : https://doi.org/10.46912/jbrcp.161
}

\author{
*Correspondence \\ Dr.NwaforChukwuemeka Charles : firstcocsin@yahoo.com
}

\begin{tabular}{|l|l|}
\hline $\begin{array}{l}\text { Article } \\
\text { information }\end{array}$ & $\begin{array}{l}\text { Date Submitted: 13/4/2020 } \\
\text { Date Accepted: 1/5/2020 } \\
\text { Date Published: June, 2020 }\end{array}$ \\
\hline
\end{tabular}

\begin{abstract}
Ascites is a symptom that can originate due to diverse pathologies. A lot of investigations including ascitic fluid cytology $(A F C)$ can be done on it to help determine its origin. The aim of this study, is to document the findings and highlight the importance of AFC in patient care in Uyo. All AFC reports and slides in the Department of Histopathology, University of Uyo were retrieved, reviewed and used for this study. The age ranged from $1.5-80$ years with mean age, $41.79( \pm 17.23)$ years. About $71.8 \%$ of the ascitic fluid $(A F)$ specimens were from patients between the $3 r d$ and 6 th decade. Females predominated in all age groups expect 10-19 year's group, with a male to female sex ratio of 1:2.4. Malignant cells were seen in $28.7 \%$ of all the samples, while $51.2 \%$ were negative for malignant cells. Malignant cells were seen in 4 (6.7\%), 11 (18.3\%) and $6(10 \%)$ of the AFC performed due to various liver pathologies, ovarian malignancies and intra-abdominal malignancies respectively. Malignant cells were found more in females with a male to female ratio of 1: 3.6. Age group 40-49 years accounted for most of the malignant cases (26.6\%). The pattern of AFC in Uyo is similar to the pattern in other parts of Nigeria.
\end{abstract}

Keywords: Ascitic fluid cytology, Cytologic diagnosis, Malignant cells, Positive smear

\section{INTRODUCTION}

\begin{abstract}
A scites is the pathologic accumulation of fluid in the peritoneal cavity. It is not a disease but a symptom that can originate due to diverse pathologies of any of the following; hepatic, malignant, cardiac, renal and infectious diseases. ${ }^{1-5}$ These diseases could be inflammatory, benign or malignant. To achieve a successful treatment in each patient with ascites, adequate diagnosis is important. ${ }^{1-9} \mathrm{~A}$ lot of biochemical tests like (serum-ascites albumin gradient, total protein, adenosine
\end{abstract}

deaminase activity, glucose and lactate dehydrogenase, urea and creatinine, amylase and triglycerides) and nonbiochemical tests like (polymorphonuclear leukocyte count, bacterial cultures, PCR bacterial DNA Mycobacterium tuberculosis and cytology) can be done on the ascitic fluid to help identify its source and nature. ${ }^{1-9} \mathrm{In}$ developing countries, ascitic fluid cytology (AFC) and bacterial cultures are the most commonly performed ones. AFC is a rapid, cheap, relatively non-invasive means of evaluating ascites and possibly establishing its cause. ${ }^{2,3}$ Also in situations when tissue histologic diagnoses are 
unattainable, or in patients unfit to go for biopsy or surgery, AFC may assist in making clinical diagnosis. AFC has been proven to have a low sensitivity (ranging from $56.8 \%$ - 60\%), a high specificity (which may approach $100 \%$ ) and this at times causes a significant number of false negatives. ${ }^{5,9,10}$ Despite this, in most studies malignant AFC smears ranged from 5.8\% -27.1\% and majority of these positive smears were seen in females and are mostly of ovarian origin. ${ }^{2-4,8,9}$ Apart from Papanicolaou smear for cervical cancer screening, AFC forms the next major bulk of cytologic specimens received in our department. Our aim is to know its pattern and to which extent the requesting physician's question is answered.

\section{MATERIALS AND METHODS}

All AFC reports and slides in the Department of Histopathology University of Uyo Teaching Hospital (UUTH) archives, from January $1^{\text {st }}, 2006$ to December $31^{\text {st }}, 2018$ were retrieved, reviewed and used for this study. When the ascitic fluid (AF) specimens are brought to the department, unique cytological numbers were given to each specimen. Immediately after, macroscopic descriptions (colour and quantity) were noted and the fluid centrifuged at 3000 revolutions per minute for five minutes. The supernatant was discarded and the remaining sediment were transferred with the help of pipette onto clean microscope glass slides and spread evenly. Two to three slides were air dried and stained with May-Gruwald-Giemsa stain. One slide was immediately fixed in 95\% alcohol and stained with Papanicolaou (Pap) stain for cytological evaluation. Following this preparation, each set of slides (for each AF) were examined using a binocular light microscope and classified into major categories based on the presence or absence of malignant cells and any other cells present: positive smear, suspicious smears (containing atypical cells), inflammatory smears (containing only inflammatory cells) and unsatisfactory (inadequate smears). A positive (a malignant smear) cytology was confirmed by the presence of pleomorphic cells, with raised nucleocytoplasmic ratio, irregular membrane borders and coarse clumped chromatin.

The extracted data were entered and analyzed using Statistical Package for Social Sciences (SPSS) version 20.0 incorporated, Chicago Illinois USA. These data are presented in tables and bar charts as frequencies and percentages.

Reports without any of the major demographic information like age or sex or those without the cytological diagnoses were excluded. Ethical approval was obtained from UUTH research ethical committee.

\section{RESULTS}

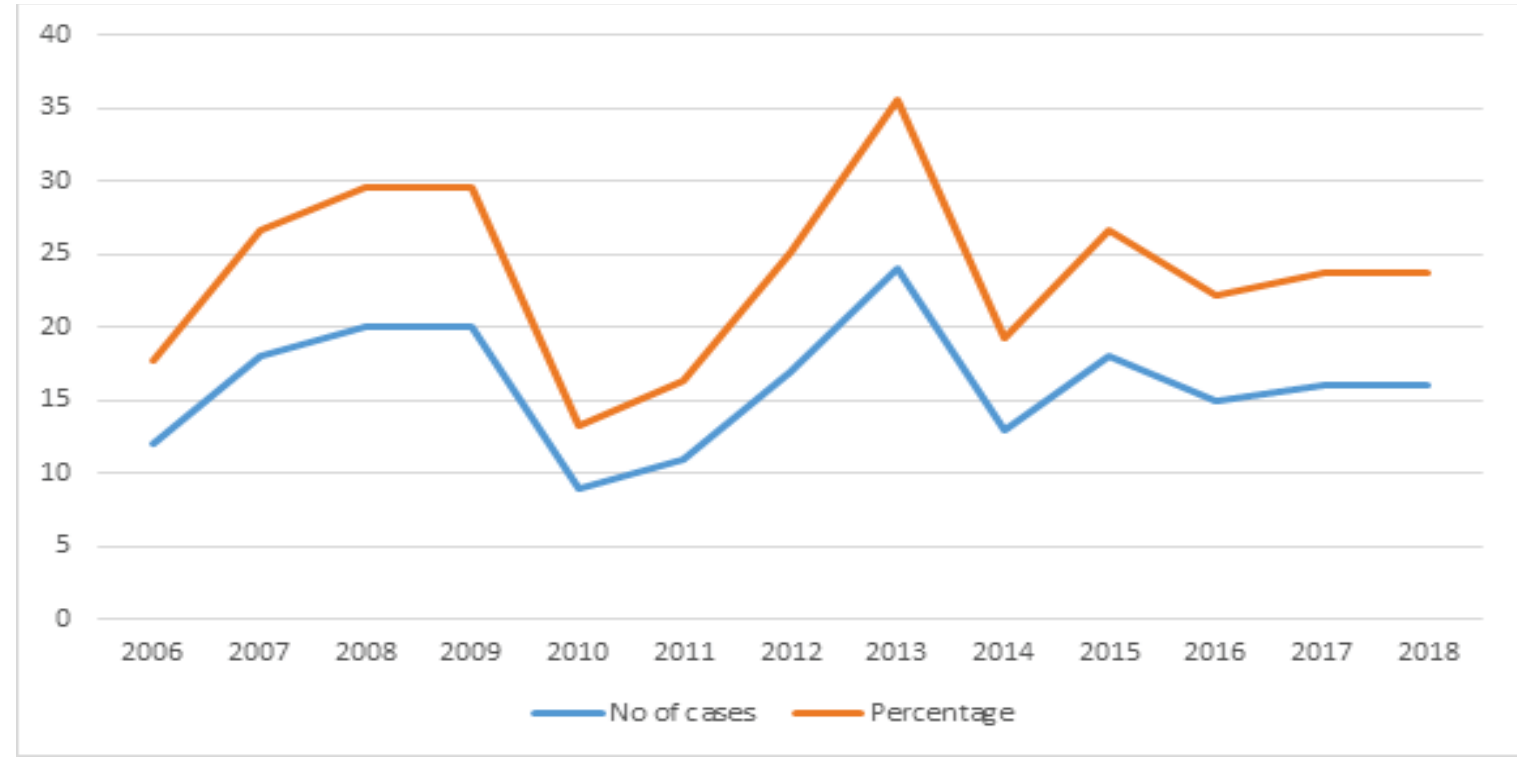

Figure 1: Yearly distribution of cases 
Figure 1, shows the yearly variation of AFC specimens received in the department, with the lowest occurring in the year 2010 and the peak in 2013. From 2014 to 2018, it maintained a fairly stable frequency. The youngest patient was a 1year 5 months old male and the oldest was an 80year-old male, with a mean age of $41.79( \pm 17.23)$. About $71.8 \%$ of the AF specimens were from age group 20-29 years to 50-59 years and each of these 4 age groups contributed fairly about the same percentage as shown in table 1. Females predominated in all age groups expect in 10-19 years age group, with a male to female sex ratio of $1: 2.4$. Forty-six percent of request for AFC were from department of Internal Medicine, followed by 23\% requested by gynecologists as shown in figure 2 .

Table 3 shows the cytologic diagnoses (CD), with malignant cells seen in $28.7 \%$ of AFC. In majority of the AFC (51.2\%), they were negative for malignant cells. Malignant cells were seen in 4 (6.7\%), $11(18.3 \%)$ and 6 $(10 \%)$ of the AFC performed due to various liver pathologies, ovarian malignancies and intra-abdominal malignancies respectively. No association was observed between $\mathrm{CD}$ and indication for AFC $(\mathrm{p}=0.010)$. Minimum quantity of AF was $1 \mathrm{ml}$ and a maximum of $820 \mathrm{ml}$ with a mean volume of $26.90( \pm 79.91)$. No significant association was seen between age group and sex for the malignant AFC cases, though malignant $\mathrm{AFC}$ was seen more in females with a male to female ratio of 1: 3.6. Age group 40-49 years accounted for $26.6 \%$ of the malignant cases, followed by age group 50-59 years which accounted for $21.7 \%$ of cases as shown in table 4 .

Table 5 shows a comparison of the index study with other similar studies. Others include: 3 cases of chronic kidney disease, 2 cases each of pancreatic carcinoma and endomyocardial fibrosis. A case each of the following:

Table 4: Age and sex distribution of malignant AFC cases

\begin{tabular}{llll}
\hline Age group & Male & Female & Total(\%) \\
\hline $0-9$ & 1 & 1 & $2(3.3)$ \\
$10-19$ & - & 3 & $3(5)$ \\
$20-29$ & 4 & 3 & $7(11.7)$ \\
$30-39$ & - & 7 & $7(11.7)$ \\
$40-49$ & 4 & 12 & $16(26.6)$ \\
$50-59$ & 3 & 10 & $13(21.7)$ \\
$60-69$ & 1 & 9 & $10(16.7)$ \\
$70-79$ & - & 2 & $2(3.3)$ \\
Total & 13 & 47 & $60(100)$ \\
\hline$P=0.168$ & & &
\end{tabular}

neuroblastoma, hydronephrosis, bleeding per vagina, endometriosis, preeclampsia, mesenteric cyst, incisional hernia, cardiorenal syndrome, appendicitis, endometrial carcinoma, Hodgkin's lymphoma, abdominal abscess, peptic ulcer disease and lymphoproliferative disorder.

Table 1: Age and sex distribution of cases

\begin{tabular}{lllll}
\hline Age group & Male & Female & Sex-not stated & n (\%) \\
\hline $0-9$ & 2 & 3 & 1 & $6(2.9)$ \\
$10-19$ & 7 & 6 & - & $13(6.2)$ \\
$20-29$ & 7 & 30 & - & $37(17.7)$ \\
$30-39$ & 7 & 31 & - & $38(18.2)$ \\
$40-49$ & 11 & 26 & - & $37(17.7)$ \\
$50-59$ & 15 & 23 & - & $38(18.2)$ \\
$60-69$ & 8 & 20 & 1 & $29(13.9)$ \\
$70-79$ & 3 & 7 & - & $10(4.8)$ \\
$80-89$ & 1 & - & - & $1(0.5)$ \\
Total & $61(29.2 \%)$ & $146(69.9 \%)$ & $2(0.9 \%)$ & $207(100)$ \\
\hline
\end{tabular}

Table 2: Indications /Clinical diagnoses for AFC

\begin{tabular}{lrrrl}
\hline Indications & Male & Female & Total & Percentage \\
\hline Liver pathologies $(\mathrm{n}=38 ; 18.2 \%)$ & & & & \\
$\quad$ Chronic liver disease & 14 & 11 & 25 & 12 \\
Hepatoma & 4 & 3 & 7 & 3.3 \\
$\quad$ Cirrhosis & 2 & 2 & 4 & 1.9 \\
$\quad$ Hepatic cyst & - & 1 & 1 & 0.5 \\
Alcoholic liver disease & 1 & - & 1 & 0.5 \\
Ovarian malignancy & - & 31 & 31 & 14.8 \\
Abdominal malignancy & - & 12 & 12 & 5.7 \\
Abdominal tuberculosis & 5 & 12 & 17 & 18.1 \\
Ascites ? cause & 1 & 7 & 8 & 3.8 \\
Meigs syndrome & - & 5 & 5 & 2.4 \\
Others & 7 & 16 & 23 & 11.0 \\
Not stated & 24 & 39 & 64 & 30.6 \\
\hline
\end{tabular}

Table 3: Pattern of cytologic diagnosis

\begin{tabular}{lcc}
\hline Cytologic diagnosis & Frequency & Percentage $(\%)$ \\
\hline Positive for malignant cells & 60 & 28.7 \\
Suspicious & 23 & 11 \\
Negative for malignant cells $(\mathrm{n}=27 ; 51.2 \%)$ & \\
Inflammation & 77 & 36.9 \\
Negative not otherwise qualified & 27 & 12.9 \\
Reactive mesothelial cells & 3 & 1.4 \\
Unsatisfactory & 19 & 9.1 \\
$\quad$ Total & 209 & 100 \\
\hline
\end{tabular}


Table 5: Comparison of the index study with other similar studies

\begin{tabular}{|c|c|c|c|c|c|c|c|}
\hline Parameter & $\begin{array}{l}\text { Index } \\
\text { study }\end{array}$ & $\begin{array}{l}\text { Udoh MO } \\
\text { et } a l^{3}\end{array}$ & $\begin{array}{l}\text { Nwafor } \\
\text { CC et } a \mathbf{l}^{4}\end{array}$ & $\begin{array}{l}\text { Junaid T A } \\
\text { et } a l^{6}\end{array}$ & $\begin{array}{l}\text { Bodal V K } \\
\text { et } a l^{2}\end{array}$ & Maharian $\mathrm{S}^{8}$ & Karoo $\mathbf{R} \mathbf{O S}^{9}$ \\
\hline Area of study & $\begin{array}{l}\text { Uyo, } \\
\text { Nigeria }\end{array}$ & $\begin{array}{l}\text { Benin, } \\
\text { Nigeria }\end{array}$ & $\begin{array}{l}\text { Benin, } \\
\text { Nigeria }\end{array}$ & $\begin{array}{l}\text { Ibadan, } \\
\text { Nigeria }\end{array}$ & $\begin{array}{l}\text { Punjab, } \\
\text { India }\end{array}$ & $\begin{array}{l}\text { Chitwan, } \\
\text { Nepal }\end{array}$ & $\begin{array}{l}\text { Leicester,United } \\
\text { Kingdom }\end{array}$ \\
\hline Duration of study & 12 years & 5 years & 10 years & 5 years & & 5 years & 2.5 years \\
\hline Sample size & 209 & 277 & 235 & 859 & 250 & 362 & 276 \\
\hline $\begin{array}{l}\text { Mean age/ } \\
\text { Main age group }\end{array}$ & 41.79 & 46.12 & 45.01 & & 41-50 years & $50-59$ years & \\
\hline $\mathrm{M}: \mathrm{F}$ ratio & $1: 2.4$ & $1: 2$ & $1: 7$ & & $2.2: 1$ & $1: 1.1$ & $1: 1.7$ \\
\hline $\begin{array}{l}\text { Overall Percentage } \\
\text { malignant }\end{array}$ & $28.7 \%$ & $27.1 \%$ & $31.5 \%$ & $24.2 \%$ & $4.8 \%$ & $5.8 \%$ & $17 \%$ \\
\hline $\begin{array}{l}\text { Inflammatory } \\
\text { percentage }\end{array}$ & $36.9 \%$ & $33.2 \%$ & $41.4 \%$ & $69.5 \%$ & $34.8 \%$ & & $79.7 \%$ \\
\hline Unsatisfactory & $9.1 \%$ & $27.4 \%$ & $27.2 \%$ & $6.4 \%$ & $10 \%$ & & $2.9 \%$ \\
\hline
\end{tabular}

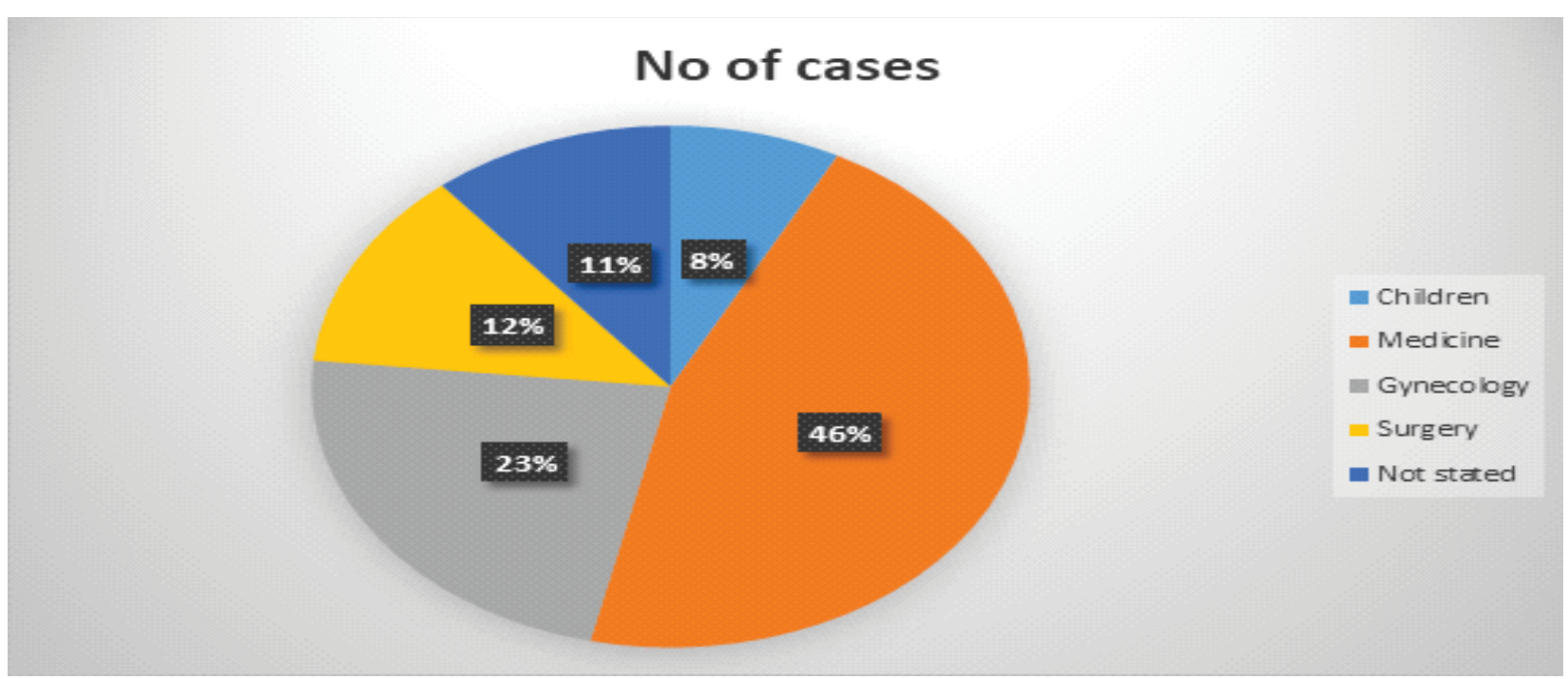

Figure 2: The distribution of departments that requested for AFC

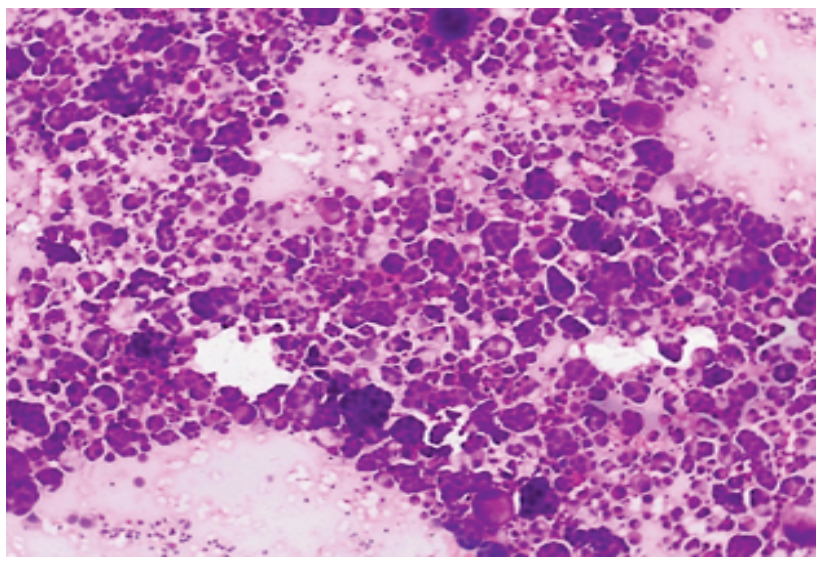

Figure 3: Positive AFC smear from a 30-year-old lady with suspected intra-abdominal malignancy (Giemsa stain; X40 magnification) showing pleomorphic cells with enlarged, hyperchromatic nuclei. 


\section{DISCUSSION}

AFC result is an important parameter in diagnosing, staging, determining therapeutic approach and monitoring of disease prognosis especially in gynecological and gastrointestinal malignancies. ${ }^{11,12}$ The female sex predominated in this study, just like most studies except the study in Punjab India. ${ }^{2}$ The reason for the male sex predominance in Punjab India, was not stated by the authors and could not be deduced. The dominance of the female sex is closely related to the indications for $\mathrm{AFC}$ in our centre, which was mainly due to ovarian or suspected ovarian malignancies. AFC has been proven to be highly specific and moderately sensitive in detection of ovarian malignancies particularly in grade 3 and 4 diseases. ${ }^{9,11,12}$ Also the low number of AFC request in males may be due to the knowledge and suggestion by some authors that if ascites is thought to be secondary to a tumor in a male, that no further invasive investigation is warranted, because it will not make a difference to the patient's long term survival. ${ }^{13,14}$

The mean age of malignant cases in this index study is similar to mean age reported in previous studies. ${ }^{2-4,8}$

The malignant smear rate of $28.7 \%$ in the index study is within the range of 24.2 and $31.5 \%$ observed in other Nigerian studies but less than rates of $4.8 \%$ in Punjab; India, 5.8\% in Chitwan; Nepal and $17 \%$ in Leicester; United Kingdom. ${ }^{2-4,6,8,9}$ The reason why most foreign studies have lower malignant rates cannot be readily explained.

Liver pathologies are usually complicated by ascites. Liver cirrhosis and hepatic malignancies account for approximately $85 \%$ and $10 \%$ respectively of AF sent for cytology. ${ }^{15,16}$ The highest documented rate of positive smears (malignant cells) reported in AFC due to hepatic malignancy is $27 \%{ }^{17}$ Non-malignant AFC results are most commonly caused by liver and heart diseases. ${ }^{12}$ Based on this, previous works have suggested that $\mathrm{AFC}$ request should be discouraged or done with caution, for liver pathologies. ${ }^{4}$ This finding is collaborated in this study, where malignant cells (positive smear) was seen in only $6.7 \%$ of $\mathrm{AFC}$ requested due to various liver pathologies. Another reason why there are many $\mathrm{AFC}$ request due to various liver pathologies in the index study, may be due to the fact that AFC is a cheap investigation in our setting costing equivalent of 5 pounds sterling, compared to 30 pounds sterling in Leicester UK. ${ }^{9}$ Hence it is usually requested during the work-up of a patient with ascites, irrespective of the suspected cause. Hence department of internal medicine that manages most liver pathologies, made request for $\mathrm{AFC}$ more than all other departments in the hospital. Also request for AFC in suspected abdominal tuberculosis also managed by internal medicine department, contributed to the high number of request by this department.

Eleven percent of specimens were reported as suspicious, which is close to $12.3 \%$ documented in Benin. ${ }^{3}$ Other studies did not make mention of this category. This may be due to the fact that in some hospitals, AFC reports that are suspicious are considered to be negative. ${ }^{2}$ The index rate of $11 \%$ is much higher than the approved rate of $5 \%$, because it is believed that this category of diagnosis serve as a waste basket, perceived as an alternative way of writing "I don't know" and offers little or no help to both the requesting doctor and the patient. ${ }^{18}$ To minimize suspicious cytologic results, repeat $\mathrm{AFC}$ should be done at later interval. ${ }^{2}$ These reports increase the suspicion of cancer and implies that other modalities should be used to evaluate these patients.

The major limitations of this work include: scanty clinical details on laboratory request forms (some ascitic fluid specimens were brought to the laboratory without any clinical details at all) and significant level of subjectivity in pathology reports due to inter-observer variability. The proportion of false "suspicious" or "atypical" cases cannot be ascertained in a descriptive study such as this. Other limitations include, lack of correlation with tissue histology, ultra sound scan and biochemical parameters like (Serum-ascites albumin gradient, Total protein, Adenosine deaminase activity, Glucose and lactate dehydrogenase, Urea and creatinine, Amylase, Triglyceride).

In conclusion, majority of AF specimens were from female patients between the $3^{\text {rd }}$ and $6^{\text {th }}$ decade. Malignant cells were seen in $28.7 \%$ of all the samples, while $51.2 \%$ were negative for malignant cells. The pattern of AFC in Uyo is similar to the pattern in other centres in Nigeria. This data will serve as a baseline data for future more extensive studies.

\section{REFERENCES}

1. Oey R C, van Buuren H R, de Man R A. The diagnostic work-up in patients with ascites: current 
guidelines and future prospects. The Netherlands Jour Med 2016;74(8):330-335.

2. Bodal V K, Banasal P, Bal M S, Suri A K, Bhagat $\mathrm{R}$, Kaur $\mathrm{N}$ et al. Analysis of ascetic fluid for cytological and biochemical findings. Research and Reviews: Journal of Medical and Health Sciences 2013;2(4):97-104.

3. Udoh M O, Ugiagbe E E. Pattern of ascitic fluid cytology in a tertiary centre: A 5 year review. Ann Biomed Sci 2016;15(2):130-136.

4. Nwafor C C, Forae G D. Cytological diagnosis of ascitic fluid in Benin, Nigeria. Nig Q J Hosp. Med. 2014;24(1)46-50.

5. Ekpe E E L, Omotoso A J. The sensitivity of cytology in the differential diagnosis of ascites among adult Nigerians in a tertiary health institution. Sch. J. App. Med. Sci; 2015; 3(2F):969972.

6. Junaid T A, Odor E I A. Cytologic diagnosis of ascitic fluid in Ibadan, Nigeria. Journal of the National Medical Association 1980;72(7):669-672.

7. Muhie O A. Causes and clinical profiles of ascites at University of Gondar Hospital, Northwest Ethiopia: Institution-Based Cross-Sectional Study. Canadian Journal of Gastroenterology and Hepatology 2019, Article ID 5958032, 8 pages.

8. Maharjan S, Ranabhat S, Tiwari M, Bhandari A, Osti B P, Neopane P. Exfoliative cytology analysis from different sites of the body. Journal of Chitwan Medical College 2017;7(20):33-39.

9. Karoo R O S, Lloyd T D R, Garcea G, Redway H D, Robertson G S R. How valuable is ascitic cytology in the detection and management of malignancy? Postgrad Med J 2003; 79:292-294.

10. Castaldo G, Oriani G, Cimino L, Topa M, Mostarda I, Castellano L et al. Total discrimination of peritoneal malignant ascitesby assay of ascitic cholesterol and lactate dehydrogenase. Clin Chem 1994;40(3):478-483.

11. Janagam C, Atla B. Study of ascitic fluid cytology in ovarian tumors. Int J Res Med Sci2017;5:522731.

12. Živadinović R, Petrić A, Krtinić D, Milosević J S, Dinić S P T. Ascites in Ovarian Carcinoma Reliability and Limitations of Cytological Analysis. West Indian Med J 2015;64 (3):236-240.
13. Parsons SL, Watson SA, Steele RJC. Malignant ascites. Br J Surg1996;83:6-14.

14. Parsons SL, Lang MW, Steele RJC. Malignant ascites: a 2-year review from a teaching hospital. Eur J SurgOncol1996;22:237-239.

15. Runyon BA, Montano AA, Akriviadis EA, Antillon MR, Irving MA, McHutchisonJG. The serumascites albumin gradient is superior to the exudatetransudateconcept in the differential diagnosis of ascites. Ann Intern Med1992;117:215-220.

16. Hou W, Sanyal AJ. Ascites: diagnosis and management. Med Clin North Am2009;93:801-817.

17. Colli A, Cocciolo M, Riva C,Marcassoli L, Pirola M, Di Gregorio P_et al.Ascitic fluid analysis in hepatocellular carcinoma. Cancer. 1993;72:677-82.

18. Cibas E S. Pleural, pericardial and peritoneal fluids. In: Cibas E S, Ducatman B S (eds) Cytology: Diagnostic principles and clinical correlates. $3^{\text {rd }} \mathrm{Ed}$. Philadelphia:Saunders Elsevier 2009; pp 129-153. 